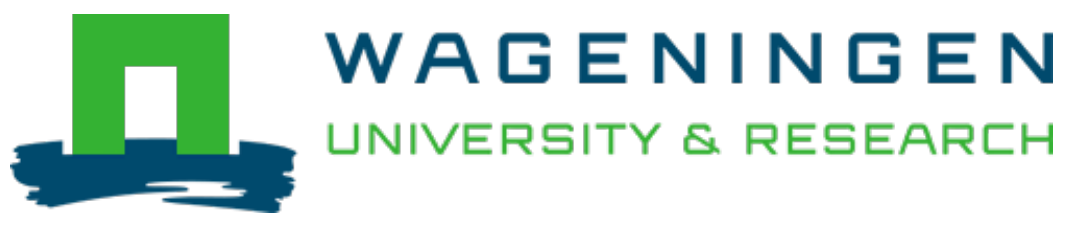

\title{
Transformative potential from the ground up : Sustainable innovation journeys, soft change and alignment of interests in urban food initiatives
}

\author{
European Urban and Regional Studies \\ Maye, Damian; Swagemakers, Paul; Wiskerke, Johannes S.C.; Moschitz, Heidrun; Kirwan, James et al \\ https://doi.org/10.1177/09697764211028887
}

This article is made publicly available in the institutional repository of Wageningen University and Research, under the terms of article $25 \mathrm{fa}$ of the Dutch Copyright Act, also known as the Amendment Taverne. This has been done with explicit consent by the author.

Article 25 fa states that the author of a short scientific work funded either wholly or partially by Dutch public funds is entitled to make that work publicly available for no consideration following a reasonable period of time after the work was first published, provided that clear reference is made to the source of the first publication of the work.

This publication is distributed under The Association of Universities in the Netherlands (VSNU) 'Article $25 \mathrm{fa}$ implementation' project. In this project research outputs of researchers employed by Dutch Universities that comply with the legal requirements of Article $25 \mathrm{fa}$ of the Dutch Copyright Act are distributed online and free of cost or other barriers in institutional repositories. Research outputs are distributed six months after their first online publication in the original published version and with proper attribution to the source of the original publication.

You are permitted to download and use the publication for personal purposes. All rights remain with the author(s) and / or copyright owner(s) of this work. Any use of the publication or parts of it other than authorised under article $25 \mathrm{fa}$ of the Dutch Copyright act is prohibited. Wageningen University \& Research and the author(s) of this publication shall not be held responsible or liable for any damages resulting from your (re)use of this publication.

For questions regarding the public availability of this article please contact openscience.library@,wur.nl 


\title{
Transformative potential from the ground up: Sustainable innovation journeys, soft change and alignment of interests in urban food initiatives
}

European Urban and Regional Studies I-16

(c) The Author(s) 2021

Article reuse guidelines: sagepub.com/journals-permissions DOI: $10.1177 / 09697764211028887$ journals.sagepub.com/home/eur

(\$)SAGE

\author{
Damian Maye ${ }^{(D)}$ \\ University of Gloucestershire, UK
}

\section{Paul Swagemakers}

University of Vigo, Spain

\section{Johannes SC Wiskerke}

Wageningen University, The Netherlands

\section{Heidrun Moschitz}

Research Institute of Organic Agriculture, Switzerland

\author{
James Kirwan \\ University of Gloucestershire, UK
}

\section{Ingrid Jahrl}

Research Institute of Organic Agriculture, Switzerland

\begin{abstract}
This paper utilises the 'sustainable innovation journeys' concept to trace how people organise and design urban food initiatives and influence city-region food policy. We evaluate whether designs succeed or fail and monitor the exchange of ideas that takes place between stakeholders. Tracing these interactions reveals the transformative potential of innovative projects, particularly if the food system changes they bring to the fore are aligned with policy interests. Three case studies provide on-the-ground insights to assess how small and medium-sized enterprises at the micro-level induce sustainability shifts. The case studies are businesses in the city-regions of Rotterdam, The Netherlands (urban farm and circular food economy); Vigo, Spain (food, forest and multi-functional land use); and Zurich, Switzerland (organic food and short supply chains). Each initiative was studied in-depth over a two-year period, with follow-up analysis for a further four years to monitor change over time (2013-2018). The cases promote the adoption of micro-level innovation practices: locally designed transition pathways that bring the benefits of change to the city-region (i.e. from the micro-level initiative to meso-level policy). The analysis highlights the importance of 'soft change'. This can be something as simple as visiting an inspiring urban food initiative and meeting with stakeholders to generate mutual understanding, from where interests align to influence food chain practices and policy. Soft changes act as 'seeds of transition' for a shift towards more sustainable urban food systems, but we observe too potentially negative impacts due to lack of alignment at the micro- (initiative) or meso- (city-region) levels.
\end{abstract}

\section{Keywords}

Alignment of interests, soft change, sustainable innovation journeys, transformative potential, urban food initiatives

\section{Introduction}

The old Fordist alliance between urban consumers, government professionals and capitalism resulted in large-scale highly effective global food systems providing cheap food to urban populations (Goodman

\section{Corresponding author:}

Damian Maye, Countryside and Community Research Institute, University of Gloucestershire, Swindon Road, Cheltenham,

GL50 4AZ, UK.

Email: dmaye@glos.ac.uk 
et al., 2012: 20; Kneafsey et al., 2021). This model, which went largely unchallenged for decades, has meant that most cities operate beyond the productive capacity of their hinterland (de Zeeuw and Drechsel, 2016; Rees and Wackernagel, 1996; Steel, 2008). Cities have become increasingly dependent on globalised chains of production, processing and distribution. Since the beginning of this century a series of well-documented 'shocks' to the food system, of which Covid-19 is the latest, have caused analysts to question the sustainability of urban food provisioning (Ballamingie et al., 2020; Maye and Kirwan, 2013). Vulnerability of urban food systems is further heightened through a series of interdependent pressures, including population growth, urbanisation, changing diets, scarcity and depletion of resources, climate change and public health concerns (Wiskerke, 2015). This has resulted in a search to find solutions to sustainability challenges in agricultural food production. These stretch from the global to the local, with studies pointing increasingly to new spatial connections at urban and regional scales (Morgan, 2015; Moschitz, 2018; Sonnino, 2009; Sonnino et al., 2019), including systems of food governance and innovations that incorporate food with other land uses (forestry, bio-economy, green infrastructure, etc.) (Maye, 2019; Wiskerke, 2015). Urban areas have become important spatial arenas to test interventions and debate food system functioning and the scope for policy engagement.

Instead of global-scale provisioning, this scholarship advocates the meso-level as a more appropriate scale to develop and implement an integrated approach to urban food systems (Deakin et al., 2019; Sonnino et al., 2016). The emergence of this new level of food system activity and associated urban activism is particularly pertinent in Europe and North America, where several cities and regions have developed highly innovative multi-level food strategies (Kneafsey et al., 2021; Marsden and Morley, 2014). This includes city councils (e.g. New York), who have developed city- and regional-level food strategies to better manage resources and land in and around the city's rural hinterland (Wiskerke, 2015) and urban food policy councils (e.g. Toronto Policy Council, Kansas City Food Circle, Bristol Food Policy Council, Cork Food Policy Council)
(Giambartolomei et al., 2021). These regional policy innovations signify new modes of collective entrepreneurship alongside a growing urban consumer movement that is seeking new ways to buy and grow food and is actively constructing new civic alliances, often in combination with innovations in digital technology (Goodman et al., 2012; Sonnino et al., 2016; Wiskerke, 2009). Increasing interest in food and rural issues in urban policy has also led to a growth in 'city food planning' and the re-emergence of concepts such as 'continuous productive urban landscape' that reimagine cityscapes as socio-ecological spaces (Morgan, 2015).

An important aspect of urban agriculture and city food planning, which forms the focus of this paper, is innovation at the level of specific iconic projects or initiatives within a city (i.e. the micro-level). More specifically, we examine urban food initiatives that are well-known in their respective city to understand both their design and wider influence in enabling urban food system change. Focusing on micro-scale urban agri-food innovations captures less obvious but critical social innovation relations and processes as capacities that potentially transform the urban food system and regional policy network. We trace, using the 'sustainable innovation journeys' concept (Langendahl et al., 2016), how micro-level innovation practices potentially bring 'soft change' benefits to a city-region by influencing policy networks at the meso-level. When describing sustainable food systems, or urban policy development more generally, sustainability transition studies often look for evidence of 'big transformative change' as accelerators to more liveable food arrangements. We argue that 'softer', more gradual, changes are equally important to understand the innovation journey of specific initiatives and associated local city-region food policy impacts, whether through dissemination of best practice or alignment of interests that trigger social and material relations. Soft change as alignment of interests can be made through events such as field visits or workshops, social relations among practitioners involved in an initiative or social events, which over time enrol people into activities and in so doing make them aware of wider urban food sustainability challenges. Alignment of interests at the micro- and meso-levels is overlooked but is critical 
to evaluate and better appreciate processes of soft change and the enabling influence and transformative potential of urban food initiatives.

To develop this argument, the 'sustainable innovation journeys' concept is employed as a diagnostic tool to guide a practice-orientated analysis of project-level changes. This enables a micro-level biographical analysis of innovation, highlighting the importance and value of understanding social practices, institutions and the local environment in which change takes place - that is, assessing capacity for sustainability transformation from the ground up (Hargreaves et al., 2013). The aim is to trace practices, interactions and alignment at the micro-level, determine how they influence changes at the mesolevel (city/city-region), and how this relates to urban policy development. After outlining the framework for our analysis, which builds on sustainable food system transition and social innovation studies (Maye, 2018), we introduce the three case studies, their city-region context and the data collection process. The section titled A micro geography of soft change using sustainable innovation journeys examines the three business initiatives as urban food system innovations, including evidence of soft change. The material reveals an enabling role for 'sustainability transition' through alignment of interests among practitioners in innovative business cases (the micro-level) and a city-region's governance environment (the meso-level). The final section considers the implications of these findings for urban and regional policy as place-based strategies to overcome sectoral thinking and urban and rural spatial fixing.

\section{Understanding soft change: Rationale and conceptual framework}

In this paper, 'softer', more gradual changes are important to understand the transformative potential of urban food initiatives. Soft changes may be overlooked because they are messy, difficult to quantify or evidence as linear cause-effect relations. This argument is partly inductive, built up from several years of epistemologically grounded observational fieldwork, dialogue and analysis with the cases presented herein and elsewhere (all authors have spent time working closely with urban food growing projects in their respective countries, for example). It is borne too from a frustration with transition management studies now widely applied to food and environmental policy fields (Lachman, 2013) as 'niches' or 'novelties' unfolding within socio-technical regimes (i.e. systems of rules and principles). 'Transformative capacity' becomes the ability of systems to reconfigure and move towards new, more sustainable states (Wolfram, 2016). This is a product of how transition is conceptualised, with actions, behaviours and processes of change delineated by replacing socio-technical principles. It is appealing because it provides coherency, with innovation as vertical interaction between levels, that is, the level of the landscape, regime and niche (Geels and Schot, 2007), but is limited when applied to urban food transition contexts because it fails to adequately capture softer, slower, place-based relational effects.

To build our conceptual case for soft change we proceed in the following sequence of steps, which starts by re-grounding transition as horizontal linkages in place. We introduce 'sustainable innovation journeys' as our analytical framework to examine soft change in place via urban food initiatives, looking specifically at people, visions and artefacts. Urban food initiatives (as people, visions, artefacts) generate material and social relations that hold them together in place and, when traced horizontally, potentially lead to transformative change in the cityregion. We examine this through alignment of interests, generated as social relations in specific socio-material contexts.

\section{A micro geography of soft change using sustainable innovation journeys}

We are not alone in our critique of certain aspects of transition studies, with a now burgeoning literature examining transformation pathways, including relational frameworks to assess transformative social innovation and change agents in transitions (Pel et al., 2020), whilst other perspectives examine interactions within and between levels (Maye, 2018; Seyfang and Haxeltine, 2012). This reflects the reality that transforming socio-technical regimes is not 
easy (Seyfang and Smith, 2007). Under sustainability transition studies the focus has also shifted towards examining socio-technical innovations that are in accordance with sustainability agendas (Hinrichs, 2014; Lachman, 2013; Smith et al., 2010; Westley et al., 2011) and developing resources and pathways to greater sustainability (Maye and Duncan, 2017). Grassroots social innovation scholarship asserts that system change is inherently grounded, which means assessing horizontal linkages as innovation in place emergent through existing spatially embedded systems (Maye, 2019).

Building on this work, we argue it is instructive to take a micro-level perspective to examine processes of soft change, including the way agendas become aligned or not through interaction and connections made possible through, in this case, urban food projects or initiatives. Societies, places, communities and businesses are not simply passive agents who experience transitions to sustainability; they may also 'intentionally act to construct them' (Hinrichs, 2014: 145). This involves moving beyond understanding interactions between levels (i.e. a vertical analytical lens) towards social practices as they take place at the micro-scale (i.e. horizontal lens). This emphasises 'the social organisation, continuities and possible ruptures in people's everyday practices' (Hinrichs, 2014: 149).

We employ the 'sustainable innovation journeys' concept as a diagnostic tool to guide a practice-orientated analysis of project-level changes. Systems of practice approaches emphasise the need to understand how practices co-evolve across different places (i.e. different social practices in place). To understand dynamics between social practices and the practices of associated systems, scholars have developed the notion of 'sustainable innovation journeys'. This metaphor is widely used in transition studies to describe transitions to more sustainable socio-technical systems, typically at high-level scales, for example food systems, nations, societies. Whilst this contributes to understanding transformative capacity, Langendahl et al. (2016) identify a lack of work on innovation journeys at the firm level.

Innovation, they argue, particularly environmental innovation, is a complex, contingent and messy process, which is unsatisfactorily accounted for in model pathway studies. As they put it, 'it is increasingly accepted that innovation does not emerge from a linear process, which proceeds from plan to implementation' (Langendahl et al., 2016: 110). They view the sustainable innovation journey in a firm, in our case urban farm innovation initiatives, as a bundle of practices that are developed and redeveloped over time, and argue that practices can be explored by focusing on three interlocking elements (Langendahl et al., 2016: 111-112).

- People are the carriers of practices and form a dynamic element, because people in firms have different roles and they may move between and beyond firm practices. Crucially, people are not just the individuals actively involved in the firm's practice or staff but also include consultants, customers, suppliers and regulators.

- Visions comprise the knowledge and meaning required of practices. Visions are important because they can shape the development of practices (innovations). Visions are elements of practice in which people participate, and they cut across many practices at the firm level.

- Artefacts include technologies and other materials (e.g. buildings/infrastructure), devices (e.g. tools, machines) and literature (e.g. management frameworks, strategies, legislation) that are enrolled into a business. Such artefacts are made and used by people working in and connected to the firm (i.e. they are socially constructed), and can also be implicated in many practices at the same time.

\section{Enacting soft change through alignment of interests}

The sustainable innovation journeys framework usefully shows that when practices are performed, different interlocking elements are implicated and a firm can be shaped and reshaped based on the different elements and how they change over time. Grassroots innovation is crucial to the performance 
of practices because it can reconfigure constituting elements, for example a new practice can emerge, or practices may persist or disappear. This concept is useful to explain practices and soft changes taking place in urban food initiatives and through associated networks. The need to give more emphasis to alignment of interests in the redesign of urban food systems emerges as an outcome of the social and material relations expressed (Wiskerke, 2003). Interests can align around urban food system change because of a project and its vision (i.e. soft changes beyond the project itself). Alignment of interests is made possible through events such as field visits or workshops, but also eating out and other social events, which enrol people into certain activities and make them aware of urban food sustainability issues.

Practices in this context are about describing more than what people do; changes in practice cannot be explained and reduced to changes in attitude or behaviour. This reiterates the 'systems of practice' perspective, as developed by Watson (2012) and others. The social practice of cycling, for example, can influence the meanings and discourses around it. Transitions can gather momentum around relatively soft changes (e.g. increasing recruitment of cyclists, more urban food growers), which can eventually become sufficiently normal, mundane and viewed as legitimate modes of transport or food growing, in turn shifting how roads or food systems are designed, the priority given to cyclists on roads, urban land for growing, etc. (Langendahl et al., 2016). Innovation processes can be understood as the co-evolution of practices, as well as understanding the opportunities to change the practices of associated systems - the wider institutions and legislation governing a city's food system, for example. This moves from the examination of isolated practices (e.g. of an urban farm initiative) to examining how those practices influence associated systems (the urban food system). Soft changes have transformative potential within urban government environments, assuming a receptive policy and organisational audience, which, as we will see, is not always guaranteed or sustained over time.

\section{Case studies, materials and research methods}

Three city-regions were selected to examine urban food strategies and innovations that were designed respectively to close the cycles of organic waste, water and nutrients (Rotterdam, the Netherlands); use land in urban and peri-urban areas in multi-functional ways (Vigo, Spain); and encourage organic food sales using short food chains (Zurich, Switzerland). Each case study focuses on a particular business initiative that aims to improve one of the three thematic strands that collectively signify key pillars for improved urban food sustainability, as well as showing integration across the three strands. The case study regions and business initiatives were originally selected and surveyed as part of a larger FP7 project, entitled SUPURBFOOD 'Towards sustainable modes of urban and peri-urban food provisioning'. The project ran from October 2012 to September 2015 but data collection and analysis of the businesses reported here continued until November 2018, with the post-SUPURBFOOD phase of data collection designed to monitor business-level developments and changes (alignments) over time.

The governance context for each case study is different. The Metropolitan Region of Rotterdam and The Hague (2.2 million inhabitants) consists of 23 municipalities, which includes cities along the river Maas but also more coastal and inland-orientated municipalities. The city of Rotterdam (approximately 635,000 inhabitants), the second-largest in the Netherlands, is home to Europe's largest seaport. In the city-region, urban agriculture became part of the formal planning process in 2011, with a crucial role played by the Think Tank on Urban Agriculture. The city has been pioneering in several urban agriculture innovations, including the following:

- The use of a civil servant platform to discuss the potential of urban agriculture as a solution to urban policy goals, such as improving public health;

- Consideration in sustainable economic development and improving spatial quality; 
- The elaboration of a policy document in which urban agriculture was defined as farming both within and around the city; and

- The implementation of the Regional Food Council Rotterdam, to institute the continuity of food and urban agriculture policies (see http://www.rotterdam.nl/foodcouncil; last accessed 24 December 19). Formally, the Food Council still exists but it has not been active for a long time.

The Think Tank on Urban Agriculture created an enabling environment for the development of a range of urban agriculture businesses and initiatives, of which UIT JE EIGEN STAD ('From your own city'), the urban agriculture initiative examined here, became one of the most iconic examples.

The more collaborative governance approach in Rotterdam contrasts with the Vigo case, whose policy environment is more technocratic. The cityregion of Vigo, with 480,000 inhabitants, is the most densely populated area in Galicia. Vigo is Galicia's largest city (approximately 300,000 inhabitants), and its industrial capital. Large parts of the region consist of multi-functional mountainous areas covered by trees, bushes and scrubs (termed 'monte' in Galician). The dynamics in this case respond to the pressure of externally defined land-use plans for a wind park and mining activities with few societal benefits, and the risk of expropriation of commonly managed land for entrepreneurial projects. In Galicia, Neighbourhood Communities for the Common Management of Monte (Comunidades de Montes Veciñais en Man Común (CMVMC)) legally represents democratic and autonomous governance authorities, at the parish level. The analysis focused on one of the more progressive associations of this type, CMVMC Vincios (about 2000 inhabitants). Out of the total 24,400 hectares of common land in the city-region, this neighbourhood association manages 678 hectares. They run a number of projects to support Vincios' inhabitants, as well as other (urban) dwellers in the city-region. However, urban and regional policies are poorly developed or have a fundamentally different scope, and therefore transformative potential is at risk in terms of practices at wider sectoral levels.
The Zurich case is centrally organised and focuses on organic farming. The city-region of Zurich has 1.83 million inhabitants (Zurich itself has approximately 390,000 inhabitants). Although land is mainly in use as grassland, with a mix of dairy and meat production, $40 \%$ is for arable crops. The city of Zurich also has some vegetable producing farms. However, due to urban pressure, agricultural land decreased by about $8 \%$ between 1985 and 2009. At the time of data collection, $11 \%$ of farms in the cityregion were certified organic, which was slightly below the Swiss average in that year (12.8\%; increased to $14.6 \%$ in 2019), whilst in the city itself the organic share of farms is $50 \%$ (80\% in 2019). In 2014, Zurich created a vision to be a sustainable city-region by the year 2025 . This vision was framed around the idea of the '2000-Watt-Society', with targets to reduce energy consumption and $\mathrm{CO}_{2}$ emissions, and to support renewable energy sources. Food was not addressed in this vision, although in and around the city there is a long-standing tradition of short food chains and direct marketing. By 2018, sustainable food had gained more importance at city administration and policy levels. For example, Zurich signed the Milan Urban Food Policy Pact and 'sustainable food' was a key topic in an important environmental development strategy paper ('Masterplan Environment 2017-2020'). In 2019, the city designed a food strategy (Stadt Zürich) to improve food system sustainability and healthy diets. In parallel, Food Forum Zurich (www. ernaehrungsforum-zueri.ch) was established after a longer social movement process in 2018, and now represents a food council including $100+$ members: producers, businesses, interest groups and individuals. In the paper, we examine Pico Bio, a wholesaler who has had a major role in organic food distribution in the city.

\section{Data collection and analysis}

Small and medium-sized enterprises (SMEs) from each city-region were active partners in the research. The case studies were central to the design of the research and partners that represented the cases had the opportunity to feed into the direction of the research as part of an inclusive action-orientated 
approach. The three business initiatives were studied in-depth over a two-year period (2013-2014), which involved interviews and detailed case-level fieldwork with leaders of each project and related stakeholders. The field research adopted a qualitative, micro-sociological approach, which included indepth interviews with case study partners, employees, entrepreneurs, farmers, administrative personnel of associated municipalities and consumers. Interviews were combined with documentary analysis and participant observation. Data from the case studies were analysed and discussed at stakeholder meetings. This initially involved holding a workshop in each city-region to share results of the first round of analysis, supported by a detailed report of each case (Dominguez Garcia et al., 2013; Schmid and Jahrl, 2014; Van der Schans, 2014), and the organisation of an international seminar on short chains, waste and nutrient cycles and multi-functional landuse innovations.

The second stage of analysis focused on specific aspects of urban food system governance related to short chains, waste and nutrient cycling and multifunctional land use, with SME representatives coauthoring outputs (Grando et al., 2015; Koopmans et al., 2015; Schmid et al., 2015). The results were presented via a second city-region workshop and SMEs and business cases in each region were given the opportunity to provide further input. Tracking the development of the three case studies continued beyond the life of the SUPURBFOOD project. From 2015 to 2018, researchers in each case monitored critical events and updated the innovation journey biographies. This was completed twice a year via email exchanges and/or face-to-face meetings with practitioners in the field, designed to trace transformative capacity in the three case studies over time.

\section{Tracing urban food innovation in three European cities}

Each case starts with a short biography of the firm/ initiative studied in each city-region, followed by analysis of innovation in practice through people, visions and artefacts (Table 1). By describing the sustainable innovation journey and associated practices of each case study, we reveal transformative capacities (i.e. what things changed because of the practice at the initiative and city-region levels). The final section of each case study examines alignment of interests that formed because of the innovation practices and impacts in terms of urban food system governance.

\section{City farm, Rotterdam: Urban agriculture and circular economy}

UIT JE EIGEN STAD ('From your own city') started as a 2-hectare urban farm in Rotterdam in September 2012. Its founders used intensive production methods (aquaponics, vegetables, mushrooms and poultry) and opened a farm shop and a restaurant. In the initial interviews with the founders they clarified their aim to achieve economic viability for farm activities and to recycle urban waste. The modular farming operations together would finally have to create a closed system in which outputs of one module became inputs for another, and emissions were minimised. The closed system for nutrient recycling was the initial interest for the research, but the modular way of working and the enthusiasm and excitement of its founders made it fascinating to study. After several (from a business viewpoint separated) modules closed down, the project finally went bankrupt, and ended in November 2018. From inception to closure the initiative attracted significant interest and discussion even though it eventually failed as an innovation. In the Rotterdam case then we have an example of a lack of alignment at the micro-level, which is further impacted by changing city development priorities at the meso-level (from alignment to separation).

People, visions, artefacts. In the first meetings the three founders, with backgrounds and professional experience in social farming, real estate development and business consultancy, clarified their aim and vision to produce directly for consumers on a vacant, previously industrial, plot (Table 1). Although they considered the site to be large enough ( 2 ha) for what they called 'a real urban farm', its soil was polluted and without legal agrarian or hostelry designation. Staff members of the municipality 
Table I. Sustainable innovation journeys.

\begin{tabular}{|c|c|c|c|}
\hline Case study & People & Visions & Artefacts \\
\hline $\begin{array}{l}\text { Urban farm, } \\
\text { Rotterdam }\end{array}$ & $\begin{array}{l}\text { Three entrepreneurs but } \\
\text { different visions/values } \\
\text { Staff members of the } \\
\text { Rotterdam urban planning } \\
\text { department involved in } \\
\text { the Think Tank on Urban } \\
\text { Agriculture }\end{array}$ & $\begin{array}{l}\text { Reconnect urban dwellers } \\
\text { with food production } \\
\text { Establish a profitable city } \\
\text { farm business model } \\
\text { Circular economy }\end{array}$ & $\begin{array}{l}\text { Integrated farming system } \\
\text { Intensive production methods } \\
\text { Aquaponics } \\
\text { On-site shop and restaurant }\end{array}$ \\
\hline Vincios, Vigo & $\begin{array}{l}\text { Members of the forest } \\
\text { community (inhabitants of } \\
\text { the parish) } \\
\text { Beneficiaries: inhabitants of } \\
\text { the parish (directly), urban } \\
\text { dwellers (indirectly) and } \\
\text { workers (employment) }\end{array}$ & $\begin{array}{l}\text { Diversify forest management } \\
\text { in the area of the communal } \\
\text { forest; generate economic } \\
\text { activity that can be managed } \\
\text { by individuals in charge of } \\
\text { the different activities } \\
\text { Modernise the 'old principle' } \\
\text { of monte areas to be } \\
\text { supportive to the food } \\
\text { production system and local } \\
\text { society }\end{array}$ & $\begin{array}{l}\text { Institutional, juridical embedding of } \\
\text { the forest community (i.e. land in a } \\
\text { common-pool resource regime) } \\
\text { Protection of the environment } \\
\text { (reduce risk on forest fires) and add } \\
\text { value to alternative land-use activities } \\
\text { (social, ecological and economic } \\
\text { valorisation) } \\
\text { Improve soil fertility, turn 'waste' } \\
\text { (forest biomass) into organic compost } \\
\text { as well as the conservation of the } \\
\text { cultural patrimony }\end{array}$ \\
\hline $\begin{array}{l}\text { Pico Bio, } \\
\text { Zurich }\end{array}$ & $\begin{array}{l}\text { Founders: three farmers } \\
\text { in the Zurich area; } \\
\text { employees; producers and } \\
\text { processors (as suppliers); } \\
\text { customers: restaurants, } \\
\text { caterers, local shops }\end{array}$ & $\begin{array}{l}\text { Sell authentically produced } \\
\text { organic products that are } \\
\text { sourced regionally } \\
\text { Fair purchase policy and } \\
\text { support an organic food } \\
\text { chain with long-lasting } \\
\text { trade relationships; and } \\
\text { build connections between } \\
\text { producers and consumers }\end{array}$ & $\begin{array}{l}\text { High-quality organic products } \\
\text { Management and logistics of buying } \\
\text { and selling locally } \\
\text { Regional distributor for organic farms } \\
\text { in the Zurich city-region }\end{array}$ \\
\hline
\end{tabular}

arranged a permit under the condition that at least 0.5 meters of good top soil would be added to the site, and provided financial support for the start-up phase, together with personal investments of the three founders, bank loans and crowd sourcing.

In the initial phases of data collection it was evident that UIT JE EIGEN STAD was developing quite successfully, with the operation doing well to translate its vision into practice (2011-2014). It was notable that a steadily increasing number of people regularly bought produce in the on-farm shop (where produce from other nearby peri-urban farms was also sold), the number of eaters in the restaurant increased and the place was frequently booked for meetings and other events. Problems started in 2014, when one of the founders left due to different ideas about how to run the enterprise, in particular about the role of the farm in relation to the other economic activities. In later interviews they questioned the economic viability of food production in an urban context and were opposed to making money out of other services and facilities, such as the restaurant, the shop and events like meetings and parties. In an interview with one of the remaining CEOs in late 2015 , it was explained that the aquaponics system had also failed. This almost led to bankruptcy in early 2016. A new investment and the take-over by another company of the services and facilities (restaurant, shop and event space) allowed the enterprise to continue, but as two separate legal entities: the farm and the building with the restaurant, shop and event facilities. Recycling was an important feature but formal rules never allowed recycling urban waste from sources external to the farm. 
In follow-up interviews with the remaining CEOs in 2017 and 2018, the opening of a second restaurant in 2016 at Rotterdam's central railway station was highlighted. This generated a lot of criticism from Edible Rotterdam, a platform of critical urban foodies and one of the most active supporters of UIT JE EIGEN STAD during its development and start-up phase. This new restaurant, also called UIT JE EIGEN STAD, was seen to be the end of the urban farming experiment because it would replace this with a restaurant business focusing on healthy local food like many other restaurants in Rotterdam. By mid-2018, the restaurant at the central railway station had closed because it was no longer profitable. A decline in customers, also spurred by negative reviews in local newspapers, also led to a drastic reduction of opening hours and days of the first, onfarm restaurant.

Alignment of interests and transformative capacity. The development of UIT JE EIGEN STAD consisted of two episodes: a period of alignment of interests (2011-2014) and a period of separation of interests (2015-2018). The alignment period concerns alignment of interests at the micro-level (the project - i.e. the founders having a shared vision about the focus, organisation and business model) as well as between the micro-level and meso-level: its regional sociopolitical environment. The latter consisted of the Think Tank on Urban Agriculture, policy priorities at the municipal (urban agriculture policy, active support by the alderman) and metropolitan levels (priority themes of the Metropolitan Region of Rotterdam Den Haag, Regional Food Council) and support from civil society organisations, such as Edible Rotterdam. In those early years of the project, UIT JE EIGEN STAD (its vision, people and associated material artefacts) served as an inspiring example for many urban agriculture projects in Rotterdam and elsewhere in the Netherlands. Interviewees regularly spoke about its influence and the spin-off effects on other urban agriculture projects and businesses in the city. Its relative success in the early years also helped Rotterdam's urban planning department to showcase it as a successful project, which made it easier to generate political and financial support for other urban agriculture initiatives in the city.
From 2015 onwards, we see an almost opposite trajectory, both in terms of interactions among practitioners at the level of UIT JE EIGEN STAD as well as interactions between the project (the micro-level) and its regional socio-political environment (the meso-level). At the micro-level this started with the conflict between the three founders over future developments and the overarching vision, followed by a split between the farm and the restaurant due to the take-over of the restaurant business by another company, which came after the near-bankruptcy due to the aquaponics failure. Furthermore, the active supporters of the project during the early years became increasingly critical about business decisions. This coincided with a change at the mesolevel: food and urban agriculture moved from the planning to the economic development department, the interest in food shifted from local food to international food trade and logistics and the relevance of the Food Council faded away.

\section{CMVMC Vincios, Vigo: From production forests to multi-functional land use}

The neighbourhood association CMVMC in Vincios was founded in the 1980s, and manages 678 hectares of common land. Analysis of its projects and land-use adjustment activities (the microlevel), in combination with organisational principles, formal institutional arrangements and juridical practices, provides insights into how stakeholder participation in land management can be organised in a way that common land directly benefits rural dwellers connected to the land and urban residents in the wider city-region. It also provides a governance model for planners at the meso-level. The case also shows how citizens at the micro-level can initiate, organise and benefit (as a community) from a project, as well as city dwellers. However, the model is not spatially diffused and alignment of interests are not well developed between the micro (parish/community) level and the meso-level (city-region). In order to avoid failure, change in the practices of associated systems is necessary through wider institutions and legislation governing, in this case, common land use in Galicia. 
People, visions, artefacts. Vincios' sustainability orientation is anchored in the historic use of monte areas. For centuries and up until the second half of the 20th century, farming activities were performed on the basis of an 'organic agro-ecosystem' approach, which combines different land-use systems, such as crops, cattle and monte (areas of forest, scrub and bushes). Soil fertility was a determining factor for the functioning of this traditional land-use system and monte was its cornerstone. During site visits and interviews it was regularly noted that the association's core aim was to recover and restore traditional use of monte areas and to relate the functionalities of forest cleaning and biomass production to fire prevention and biodiversity production. With this historic perspective on functions of monte areas in mind, the president of the association explained during one site walk, for example, how they aimed to preserve natural and aesthetic assets and the attractiveness of the area, and to provide new functionalities to Vincios' residents and urban dwellers from the city of Vigo.

This restorative land-use approach, and activities, developed by members of CMVMC Vincios, takes a different orientation to the more commonly applied afforestation model in Galicia (in which the monoculture of eucalyptus dominates). In an assembly that meets annually and consists of 160 active participants, the members decide on the management of the common land: nowadays a diversified agro-forestry business (Table 1). At the micro-level, the implementation of projects in the common land follows a plan designed by engineers of the association and approved by the assembly. The projects are financed with revenues from renting out the land in the valley to industries and forestry activities in higher located common land in combination with regionally provided subsidies for the more innovative experimental projects. The majority of the revenue is invested in land-use differentiation and a significant part in the community itself, including the local school (meals, transport, excursions and books), music school, sports school and leisure centre.

In the common land at higher altitude, community members seek to promote biodiversity and other historic and cultural features. Pine (accompanied with mushroom production), chestnut, walnut and oak plantations and pastures have gradually replaced eucalyptus afforestation. In project meetings and interviews with technicians who assisted the community in developing the area, they explained how land fertility is improved by the application of seaweed (harvested at the beaches close to the mountain) and livestock owned by local farmers who have sheep, goats, cows and horses grazing on the common land. As well as providing a range of foodrelated business opportunities, in collaboration with neighbouring communities, an important grassroots innovation has been to start a compost plant. This plant could process biomass collected from the forest clean up (bushes and scrubs) and green waste from households into organic compost. The compost could be used to fertilise the common land, divided among households in the parishes delivering biomass input, or sold in bags to clients in the cityregion. The business model has been inspired by 'Abonos Lourido', which has over 15 years' business experience turning monte vegetation into compost for agricultural use. One member of the compost plant project is a technician, who explains in meetings with the community how this type of land use diminishes the risk of forest fires, which pose the greatest risk to the sustainable management of the natural resource base in Galicia. In addition to landuse differentiation, the project also aims to preserve the local, socio-cultural patrimony (www.vincios. org; accessed 23 April 2021), which is composed of archaeological sites combined with climbing, trekking and horse trails.

Alignment of interests and transformative capacity. The main transformation enabled through the association is its aim to sustain land use and challenge forest exploitation from the social, environmental and economic points of view. Vincios' vision of the sustainable management of the common land translates into a storyline, which gradually materialises into practice. At the micro-level, a long-term plan, developed by the communities' technician, guides the implementation of projects and activities. Although the sustainable innovation journey is open and uncertain, the resulting storyline and practices represent a general sense of direction among the community members and neighbouring communities, bolstered 
by scientific support. At the micro-level, inhabitants of the parish benefit directly from forest management through the maintenance of green space and small-scale investment and support for cultural activities and events in the parish. Urban dwellers in the city of Vigo and visitors from elsewhere also have free access to the area for leisure. However, at the meso-level these micro-level benefits are rarely discussed. This is evident through the reluctance at higher administrative levels to participate in stakeholder meetings and the difficulties initiators of the compost plant encountered when implementing the project, which eventually failed.

The emphasis on socio-cultural and environmental dimensions of forest management represents a radical innovation that challenges business-as-usual styles of forest management. It provides an inspiring example for other city-regions in terms of how to organise the management of green public spaces. Although some of the activities and projects have benefitted from regional subsidies, there is a weak link between the forest community and the institutional environment. Sustainability agendas at the micro- and meso-levels do not align. At the regional level, policies are designed to bring economic returns from monte areas: eucalyptus plantations in less densely populated areas will supply input to biomass plants. However, these plants are not owned and managed by forest communities. Land is rented from private and communal landowners or biomass will be bought from landowners.

\section{Pico Bio, Zurich: Social innovation through supply chain management practices}

'Pico Bio', founded in the mid-1990s, is a food wholesaler that sources organic produce from smallscale producers and then sells to restaurants, local shops and retailers in Zurich (290 customers in total). The company was founded by farmers who wanted to sell their produce collectively to shops and restaurants in Zurich. At the time of data collection, Pico Bio collaborated with around 50 producers and 42 processors (mostly dairies and butcheries). Alignment of interests are constructed along the supply chain, thanks to the company's successful brokerage function.
People, visions, artefacts. Pico Bio developed out of a farmers' marketing initiative, in which three farmers collectively sold their produce to shops and restaurants in Zurich before finally opening their own shop and restaurant in the city (Table 1). According to the founder, the innovation was intended initially to provide small farmers in and around Zurich with the opportunity to circumvent intermediaries by selling their produce directly to larger customers, thereby going beyond more traditional direct marketing initiatives. As the business developed, the wholesale branch was separated from the other elements of the business, although strong links between the two businesses remain; the case study focused on the wholesale branch (Pico Bio). In 2014, 24 people worked for the company. By 2020, this number has increased to 34 and is organised in a flat hierarchy. Many of the employees stay with the business for a long period of time. The founder of Pico Bio is still its CEO. The nature of the wholesale business means that Pico Bio needs to collaborate with producers (50) and processors (42) and 290 customers (restaurants and small shops). The 290 customers do not all sell 100\% organic products: more than half of them are restaurants and caterers that also sell non-organic food.

Pico Bio's main goals are as follows: (a) to sell authentically produced products sourced regionally; (b) to apply a fair purchase policy and support an organic food chain; and (c) to build connections between producers and consumers (Table 1). It therefore aims to provide small farms with options to sell their produce, as well as creating a link between local farms in the Zurich region and consumers in the city. This rationale and business model is in contrast with 'normal' wholesalers, who operate on a cost basis. In interviews with the CEO and further staff of Pico Bio it became clear that the two visions are not always compatible, as local organic producers are not necessarily small-scale farms. Consequently, the business has elected to on occasion source from small farmers from an economically less favoured region further afield. However, 'non-local' farms are still sourced from within Switzerland, at a distance of approximately $150-200 \mathrm{~km}$.

Pico Bio sells organic food products. Although larger farms provide products, the provision by small farms remains the cornerstone of its business model. 
Some of these smaller farmers find Pico Bio crucial as part of the whole local organic supply chain. As one farmer explained, 'such local retailers are very valuable customers for us'. As the CEO pointed out, Pico Bio increasingly faces the challenge of larger farmers finding alternative, direct marketing opportunities, and to repeatedly offering only their surplus produce of lower quality to Pico Bio. Pico Bio addressed this situation through motivating farmers to grow rare varieties of fruits and vegetables. Pico Bio started this new type of collaboration with small farmers, as they are open to experimentation with varieties. Larger farms, most often aiming at high yields, were less likely to adopt new practices, and thus less likely to join the innovation. A second innovation relates to logistics and trading relationships. The strong focus on sourcing from small farms brings higher transport costs, both as a result of longer distances from the farms to the logistic centre and the increase of the number of collaborating farms. However, the success of these new food chain dynamics anchors in the social dimension of creating and maintaining stable and long-lasting trading relationships with small farms. Pico Bio prioritises investing in these relationships over achieving higher possible economic gains by simply procuring what is provided to them locally. As one Pico Bio interviewee put it, 'sometimes personal relationships are more important than distance'.

Alignment of interests and transformative capacity. Pico Bio aims to directly link smaller-scale organic farmers and consumers and to establish long-lasting trading relationships. Next to establishing short food chains, Pico Bio creates new retail channels through experimenting with new organic varieties with small-scale farmers. In the study case, Pico Bio aligns the interest of practitioners in the supply chain: both of the farmers who supply them and of customers like restaurants and shops in the city. All have an interest in trading authentic organic produce, mainly from small producers, and with a particular focus on the Zurich city-region. This alignment of interests (visions and values) is enacted in particular by long-standing trading relationships with retail customers. These relationships enable Pico Bio to negotiate for all supply chain actors, to introduce new ideas and experiment in the business and through their customers.

The strong emphasis on the social dimension of local supply chains also represents real innovation compared to business-as-usual organic or nonorganic supply chains; here social values prevail over economic gains. As such, Pico Bio acts as an example of alternative ways of thinking and doing local and organic supply chain management. Establishing long-lasting trading relationships involves a strong social component. This helps to keep innovation within the system, supported by supply chain partners, and Zurich's city council recognises these functions and dynamics in its wider regional food strategy. In particular, alignment between organic farming and the policy framework supports SMEs via objectives that favour environmentally responsible local food produce for the city-region.

\section{Discussion and conclusion}

The selected cases represent proactive strategies to close waste and nutrient cycles in urban contexts, to use common land for multiple purposes, including food, forestry and recreational activities, and to establish short food chain businesses. Drawing on the sustainability transition literature, we adopted the 'sustainable innovation journeys' concept to inform a practice-orientated analysis of each case. The analysis shows how the three cases contribute to urban food system sustainability, but tensions, value differences and risks associated with the initiatives raise questions about the transition process at the level of city-region policy development. Through the case studies we observe soft change processes in the redesign of urban food. This includes providing a meeting point for stakeholders in a region or an inspiring example of best practice that helps to align interest between regional stakeholders about urban food governance. In the case studies, examples included how to close nutrient cycles, combine recreational land-use functions with food production and forestry, and support proximate food retail.

In the analysis we included firms/SMEs, activist networks and community projects to reflect the range and heterogeneous nature of urban food initiatives 
(Langendahl et al., 2016; Maye, 2019). For example, although focusing on the firm level, in the Rotterdam case we observed evidence of change in the government environment, initially enabling new connections and practices. Here, alignments - between food entrepreneurs and policy makers - enabled things to happen in the early phase of the project and for the benefit of the city. This was followed by a separation of interests. This lack of alignment of interests at the level of cityregion policy networks was apparent also in the Vigo case. The Zurich business initiative was more marketoriented, acting as a mediator between producers and consumers, and so is less dependent on policy alignment, but the short food chain business model has latterly engaged city- and regional-level policy makers through their regional food strategy.

From a theoretical standpoint, tracing alignment of interests over time includes evaluating impacts relative to initiatives' goals and objectives and wider strategic developments in the city-region. The analysis shows indirect effects, which in some cases emerged by accident or coincidence, and were always context specific. In Rotterdam, policy stakeholders regarded urban agriculture as an arena for experimentation and policy integration. With shifts in local governance priorities, this support eroded, and finally the components of the food initiative fell apart, which heralded the end of the experiment. In contrast, the sustainable management of common land in the city-region of Vigo by CMVMC Vincios started and remains at odds with regional government policy regarding forestry and renewable energy. The community, however, remains active despite considerable setbacks (the destructive forest fires in October 2017 in Galicia also affected the CMVMC Vincios area). In Zurich, the city has a history of direct marketing and an established sustainable city vision, so in this sense operates in a favourable innovation environment, but the case is in competition with the cost-driven wholesale food system.

Much has been written about the innovation potential of urban food initiatives, particularly the way that urban food strategies are developing alliances between food consumers and producers, and urban centres and their surrounding rural hinterlands (Giambartolomei et al., 2021; Marsden and Morley, 2014). For example, food strategies that prioritise health and well-being (Sonnino, 2016), challenge established planning policy thinking regarding green belts, connect food, energy and resources and integrate food planning and food policy (Brunori and Di Iacovo, 2014). The detailed longitudinal analysis of three specific urban food initiatives, their visions and practices, supports the argument that urban food networks initiate change and transformation through 'alignment of interests'. However, this is not easy to detect, and can be fleeting and susceptible to changing city-region priorities. The cases thus signify horizontal configurations that hold transformative potential at the micro-level of innovation in particular city-region contexts (Hargreaves et al., 2013). They highlight the importance of alignment at the micro and meso development levels. A failure or weakness of alignment explains why some urban food initiatives reveal what Seyfang and Smith (2007) call 'intrinsic benefits', which result in positive changes at a community level but are less successful in altering practices at a wider regional level.

\section{From project-level experimentation to the reconfiguration of urban food provisioning}

Food system transition perspectives question whether specific examples and alternative niche developments will scale up to form a new regime or remain as heterogeneous niche assemblages, and in turn how these grassroots initiatives influence the design and delivery of urban food policies (Maye and Duncan, 2017; Sonnino et al., 2019). Analysis of soft changes suggests that over time, in combination with alignment of interests, diffusion benefits can be more transformative than assumed at face value, which has implications for policy development. This notion of transformative capacity also identifies civil society as a key agent of change (Ballamingie et al., 2020; Pel et al., 2020). New ideas and practices can facilitate diffusion and change by replication of the project involved, by scaling up, or by translating the ideas into mainstream thinking (Maye, 2018; Seyfang and Haxeltine, 2012).

In relation to city-level governance, the sustainable innovation journey approach facilitates a deeper understanding of the relevance of soft changes for initiating change. In all three cases, we see the importance of people, visions and artefacts as 
carriers and elements of practice. The three cases have a clear vision (nutrient recycling and reconnecting urban dwellers with food production; an innovative approach to common land (restoring traditional multi-functional uses); new supply chain management practices that prioritise fair pricing and trading relations for small farmers). This visioning is important in terms of how the initiative has evolved, although it is not uncontested, as we see in the Rotterdam case where one of the original founders left because of differences regarding the direction of the farm. The evolution of initiatives takes shape and is translated through different artefacts and experimental projects, for example organic products, including lesser-known varieties (experimentation) and logistics (Pico Bio); restorative land-use techniques and practices, including a failed compost plant (Vigo); and integrated farming systems, including a failed aquaponics experiment, a failed shop and restaurant and ultimately a failed circular and multifunctional urban farm (Rotterdam).

Failure and success are measurements for transformative capacity. Observing how those practices influence alignment of interests and transformation is important (Wolfram, 2016). From the case studies, we see, for example, how the Vincios model is valued and has inspired neighbouring communities. It is supported by scientists, as well as benefiting urban dwellers who visit the site. However, alignments and influence with regional government institutions is weak because they value afforestation that generates economic value via eucalyptus for biomass. In Zurich, the transformation is producer consumer reconnection. Links with public institutions are weak. This is a private model of governance that seeks to align small farmers and shops and restaurants in the city. However, policy makers in the Zurich area also benefit from the model, and incorporate the resulting dynamics in their policy plans. Membership in the Food Forum Zurich, for example, contributes to increasing the transformative capacity of the innovation practice. In contrast, the Rotterdam case study was initially successful in connecting interests at the municipal and city-region levels (via green economy, circular economy and urban renewal policy links), as well as via civil society organisations. However, the project eventually failed due to the inability to align interests both within the farm and between the farm and the regional political environment (where the priorities shifted from supporting urban agriculture to promoting the globally leading position of Rotterdam's food economy).

In conclusion, the paper reveals the tensions, values and risks associated with such initiatives, in relation to policy development. These include the underlying values and reasons behind growing food or forestry products as a means to generate value for a business (private enterprise/economic value added) alongside the wider claims often associated with such projects as enabling new and improved ways of thinking and acting. This raises questions that are less about the transition process itself (as a managed process of change) and are more about understanding soft change processes and interactions at the micro- and meso-scales and their potential to realign urban areas to rural hinterlands.

\section{Acknowledgements}

We would like to thank the editor, Tuna Tasan-Kok, and two anonymous referees for their very helpful and constructive comments on a previous draft of the paper. We are also extremely grateful to the case study participants for their time, help, support and engagement with our work.

\section{Declaration of conflicting interests}

The author(s) declared no potential conflicts of interest with respect to the research, authorship, and/or publication of this article.

\section{Funding}

The authors disclosed receipt of the following financial support for the research, authorship and/or publication of this article: The research for this paper was undertaken as part of the 'SUPURBFOOD' project, which received funding from the European Union's Seventh Framework Programme for research, technological development and demonstration (grant agreement no 312126). The content of this publication does not reflect the official opinion of the European Union. Responsibility for the information and views expressed therein lies entirely with the author(s).

\section{ORCID iD}

Damian Maye (iD https://orcid.org/0000-0002-4459-6630 


\section{References}

Ballamingie P, Blay-Palmer A, Knezevic I, Lacerda AEB, Nimmo ER, Stahlbrand L and Ayalon R (2020) Integrating a food systems lens into discussions of urban resilience: a policy analysis. Journal of Agriculture, Food Systems, and Community Development 9 (3): 227-243.

Brunori G and Di Iacovo F (2014) Urban food security and landscape change: a demand-side approach. Landscape Research 39 (2): 141-157.

de Zeeuw H and Drechsel P (2016) Cities and Agriculture: Developing Resilient Urban Food Systems. Oxford: Routledge.

Deakin M, Borrelli N and Diamantini D (2019) City food governance: editors' introduction to the special issue. City, Culture and Society 16 (March): 1-4.

Dominguez Garcia MD, Copena Rodriguez D, Swagemakers P and Simon Fernandez X (2013) Deliverable 2.2. WP2 Final Case Study Report: The Metropolitan Area of Vigo in the North Western Part of Spain. SUPURBFOOD Project. Available at: http://www.supurbfood.eu/documents.php

Geels F and Schot J (2007) Typology of sociotechnical transition pathways. Research Policy 36 (3): 399-417.

Giambartolomei G, Forno F and Sage C (2021) How food policies emerge: the pivotal role of policy entrepreneurs as brokers and bridges of people and ideas. Food Policy. Epub ahead of print 4 February. DOI: 10.1016/j.foodpol.2021.102038.

Goodman D, DuPuis EM and Goodman M (2012) Alternative Food Networks: Knowledge, Practice, and Politics. Abingdon: Routledge.

Grando S, Jahrl I, Hegger E, Ortolani L, Carey J, Hochberg K, Marolf B, van den Bosch DP and di Pierro M (2015) WP5 Final Report. Short Chain Delivery of Food in Urban and Peri-Urban Areas. SUPURBFOOD Project. Available at: http://www. supurbfood.eu/documents.php

Hargreaves T, Longhurst N and Seyfang G (2013) Up, down, round and round: connecting regimes and practices in innovation for sustainability. Environment and Planning $A 45$ (2): 402-420.

Hinrichs C (2014) Transitions to sustainability: a change in thinking about food systems change? Agriculture \& Human Values 31 (1): 143-155.

Kneafsey M, Maye D, Holloway L and Goodman MK (2021) Geographies of Food. London: Bloomsbury.

Koopmans M, Mettepeningen E, Keech D, Reed M, Kunda

I, Tisenkopfs T, Belshaw A, Michels M, Meiberga

U, Curry N, Grivins M and Van Huylenbroeck
G (2015) WP6 Final Report. An Exploration of Multi-Functionality in Urban Food Initiatives. SUPURBFOOD Project. Available at: http://www. supurbfood.eu/documents.php

Lachman DA (2013) A survey and review of approaches to study transitions. Energy Policy 58 (July): 269-276.

Langendahl P-A, Cook M and Potter S (2016) Sustainable innovation journeys: exploring the dynamics of firm practices as part of transitions to more. Local Environment 21 (1): 105-123.

Marsden T and Morley A (2014) Current food questions and their scholarly challenges: creating and framing a sustainable food paradigm. In: Marsden T and Morley A (eds) Sustainable Food Systems: Building A New Paradigm. Abingdon: Earthscan, pp. 1-29.

Maye D (2018) Examining innovation for sustainability from the bottom up: an analysis of the permaculture community in England. Sociologia Ruralis 58 (2): 331-350.

Maye D (2019) 'Smart food city': conceptual relations between smart city planning, urban food systems and innovation theory. City, Culture and Society 16 (March) : 18-24.

Maye D and Duncan J (2017) Understanding sustainable food system transitions: practice, assessment and governance. Sociologia Ruralis 57 (3): 267-273.

Maye D and Kirwan J (2013) Food security: a fractured consensus. Journal of Rural Studies 29 (January): 1-6.

Morgan K (2015) Nourishing the city: the rise of the urban food question in the Global North. Urban Studies 52 (8): 1379-1394.

Moschitz H (2018) Where is urban food policy in Switzerland? A frame analysis. International Planning Studies 23 (2): 180-194.

Pel B, Haxeltine A, Avelino F, Dumitru A, Kemp R, Bauler T, Kunze I, Dorland J, Wittmayer J and Jørgensen MS (2020) Towards a theory of transformative social innovation: a relational framework and 12 propositions. Research Policy 49 (8): 104080.

Rees W and Wackernagel M (1996) Urban ecological footprints: why cities cannot be sustainable - and why they are a key to sustainability. Environmental Impact Assessment Review 16 (4): 223-248.

Schmid O and Jahrl I (2014) Deliverable 2.2. WP2 Final Case Study Report: City Region of Zurich (Switzerland). SUPURBFOOD Project. Available at: http://www.supurbfood.eu/documents.php

Schmid O, Dominguez Garcia MD, Van der Schans JW, Guyer LGC, Fritschi R, Bachmann S, Swagemakers P, Simón Fernández X, López A and Covelo J (2015) WP4 Final Report. Closing of Nutrient, Water and 
Urban Waste Cycles in Urban and Peri-Urban Agriculture. SUPURBFOOD Project. Available at: http://www.supurbfood.eu/documents.php

Seyfang G and Haxeltine A (2012) Growing grassroots innovations: exploring the role of community-based initiatives in governing sustainable energy transitions. Environment and Planning C: Government and Policy 30 (3): 381-400.

Seyfang G and Smith A (2007) Grassroots innovations for sustainable development: towards a new research and policy agenda. Environmental Politics 16 (4): 584-603.

Smith A, Voß J-P and Grin J (2010) Innovation studies and sustainability transitions: the allure of the multilevel perspective and its challenges. Research Policy 39 (4): 435-448.

Sonnino R (2009) Feeding the city: towards a new research and planning agenda. International Planning Studies 14 (4): 425-435.

Sonnino R (2016) The new geography of food security: exploring the potential of urban food strategies. The Geographical Journal 182 (2): 190-200.

Sonnino R, Marsden T and Moragues-Faus A (2016) Relationalities and convergences in food security narratives: towards a place-based approach. Transactions of the Institute of British Geographers 41 (4): 477-489.

Sonnino R, Tegoni CLS and De Cunto A (2019) The challenge of systemic food change: insights from cities. Cities 85 (February): 110-116.
Steel C (2008) Hungry City: How Food Shapes Our Lives. London: Vintage Books.

Van der Schans JW (2014) Deliverable 2.2. WP2 Final Case Study Report: Overview Report Rotterdam City Region. SUPURBFOOD Project. Available at: http:// www.supurbfood.eu/documents.php

Watson M (2012) How theories of practice can inform transition to a decarbonised transport system. Journal of Transport Geography 24 (September 2012): 488496.

Westley F, Olsson P, Folke C, Homer-Dixon T, Vredenburg H, Loorbach D, Thompson J, Nilsson M, Lambin E, Sendzimir J, Banerjee B, Galaz V and van der Leeuw S (2011) Tipping toward sustainability: emerging pathways of transformation. AMBIO 40 (7): 762 .

Wiskerke H (2015) Urban food systems. In: de Zeeuw $\mathrm{H}$ and Drechsel P (eds) Cities and Agriculture: Developing Resilient Urban Food Systems. Abingdon: Routledge, pp. 1-25.

Wiskerke J (2003) On promising niches and constraining sociotechnical regimes: the case of Dutch wheat and bread. Environment and Planning A 35 (3): 429-448.

Wiskerke J (2009) On places lost and places regained: reflections on the alternative food geography and sustainable regional development. International Planning Studies 14 (4): 369-387.

Wolfram M (2016) Conceptualizing urban transformative capacity: a framework for research and policy. Cities 51 (January): 121-130. 